\title{
EFFECT OF SILICON INTERACTION WITH NUTRIENTS IN RICE
}

\section{Rinny Swain, Gyana Ranjan Rout*}

Department of Agricultural Biotechnology, College of Agriculture, Orissa University of Agriculture and Technology, Bhubaneswar 751003, Odisha, India

Received - April 17, 2018; Revision - June 17, 2018; Accepted - July 21, 2018

Available Online - August 10, 2018

DOI: http://dx.doi.org/10.18006/2018.6(4).717.731

\section{KEYWORDS}

EDX map

Silicon

Rice

Differential Si uptake

Macronutrients

Micronutrients

\begin{abstract}
Present experiment was conducted by using 22 upland and lowland rice varieties grown in nutrient solution with four different concentrations of silicon (Control, 0.5, 1.0, 1.5 and $2.0 \mathrm{mM}$ ) for 30 days to observe the variable accumulation rate in Indica rice. Significant differences were observed in relative shoot growth than the relative root growth. The maximum relative shoot growth rates were observed in var. Swarna (203.45\%), var. Pratikhya (202.70\%), var. Ghanteswari (196.04\%) and var. Jyortirmayee $(154.55 \%)$ at 1.0 to $1.5 \mathrm{mM} \mathrm{Si}$ concentration after 20 days of treatment, higher concentration showed pessimistic effect. Relative shoot growth showed positive correlation with silicon accretion and highest accumulation in case of var. Swarna $(3.96 \mathrm{mg} / \mathrm{g})$ and var. Ghanteswari $(3.79 \mathrm{mg} / \mathrm{g})$ at 1.5 and $1.0 \mathrm{mM} \mathrm{Si}$ application, respectively. Among the 22 varieties used, six varieties were selected including 3-upland and 3-lowland on considering their differential Si-uptake potentials and analyzed for nutrient mobilization ability in combination with silicon. The EDX maps showed the different level of element deposition on leaf surface under $\mathrm{Si}$ influence in var. Ghanteswari. With the increase in external Si supply in each genotype, the amount of silicon deposited varies, influencing the other nutrient mobilization. Both major ( $\mathrm{P}, \mathrm{K}, \mathrm{Ca}$ and $\mathrm{Mg}$ ) and minor nutrients ( $\mathrm{Mn}, \mathrm{Fe}$ and $\mathrm{Cu}$ ) showed affirmative correlation with increase in $\mathrm{Si}$ concentration. Thus, Si supplementation in rice is a cost effective, sustainable and environmental friendly nutrient management system for enhancing rice yield.
\end{abstract}

* Corresponding author

E-mail: grrout@rediffmail.com (Gyana Ranjan Rout)

Peer review under responsibility of Journal of Experimental Biology and Agricultural Sciences.

Production and Hosting by Horizon Publisher India [HPI] (http://www.horizonpublisherindia.in/).

All rights reserved.
All the article published by Journal of Experimental Biology and Agricultural Sciences is licensed under a Creative Commons Attribution-NonCommercial 4.0 International License Based on a work at www.jebas.org.

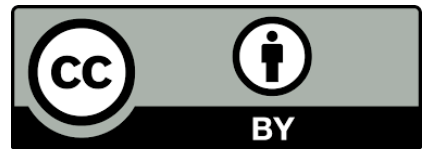




\section{Introduction}

Rice is the essential staple crop and main source of carbohydrates intake chiefly in Asia and Africa. The highest paddy growing areas are found in Asia. According to FAOSTAT (2016), India occupies second position within the world after china in terms of rice production. But, the yield of rice achieved in India is 3.6 tonnes/ha, whereas in China it is 6.9 tonnes/ha (FAOSTAT, 2016). Existence of such wide yield gap in rice is attributed to several causes including climate change, low mechanization in fields, non-availability of labors at right time, nutrient deficient soils and multitudes of biotic and abiotic stresses (Lobell et al., 2011; DACFW, 2018). The aim of 'National Food Security Mission' is to increase rice production to 10 million tons by productivity enhancement through restoring soil fertility and productivity (DACFW, 2017). However, the improved agricultural practices adopted for exaggerating yield involves the multiple use of chemicals that had resulted into numerous sorts of pollutions causing serious health concern for all living organisms. Therefore, it is essential to think in the direction of sustainable agriculture for productivity enhancement. The utilization of organic sources of nutrients will play a crucial role in achieving sustainable and environment safe agriculture. An economic and efficient soil nutrient management scheme is an indispensable facet to be considered for crop production and liable for enhancing crop productivity. The entire nutrients essential for rice production had been proposed in its fertilization schedule, incorporating all major and minor nutrients. Various studies had indicated that $\mathrm{Si}$ accumulated in plants exerts several beneficial effects on plant growth. Silicon fertilizers are additionally recommended for rice cultivation as their accumulation improves cation exchange capacities, water holding capacity, increase plant disease recovery and thus affect yield and productivity. The most noticeable beneficial effect of $\mathrm{Si}$ is an enhanced resistance to both biotic and abiotic stresses (Ma \& Yamaji, 2006). Silicon is especially important in typical Si-accumulating plants, such as rice (Oryza sativa) for healthy growth and high production (Epstein \& Bloom, 2005). Rice accumulates Si in the shoots many times higher than N, P, and K (Ma \& Takahashi, 2002; Nhan et al., 2012). However, the $\mathrm{Si}$ accumulation varies widely among different species. Japonica rice varieties generally showed higher rate of Si deposition than Indica rice varieties as reported earlier (Deren et al., 1992; Ma et al., 2007). Also, Indica rice varieties showed genotypic differences in $\mathrm{Si}$ accumulation rate (Swain et al., 2016). Ma et al. (2007) reported that the genotypic difference arise due to variation in abundance of Si transporters in rice roots.

Various studies reported that silicon based fertilization can improve growth and nutrient status of rice. Their application has consistently shown improved utilization of applied fertilizers. Silicon application in field had suggested the exploitation of appropriate mineral nutrition in plants. In 1990, Ma \& Takahashi (2002) reported that Si beneficial effects are consistent with both low and high P levels. Rana \& Masood (2002) reported that to understand metal interaction with plant, growth conditions and the presence of other ions must be studied. Silicon is well acknowledged to efficiently alleviate various chemical stresses caused by the toxicity of heavy metals like aluminum, cadmium, manganese, and iron. Williams \& Vlamis (1957) reported that the Mn toxicity in barley, which can be alleviated by addition of a minute quantity of Si. Similar interaction has been reported in beans (Horst \& Marschner, 1978), barley (Horiguchi \& Morita, 1987), cowpea (Iwasaki et al., 2002) and cucumber (Shi et al., 2005). Hammond et al (1995) reported that Si can significantly mitigate effects of Al toxicity in barley. Liang et al. (2001) observed the mitigation results due to co-deposition of $\mathrm{Al}$ and $\mathrm{Si}$, these results into formation of $\mathrm{Si}-\mathrm{Al}$ complexes that are insoluble. Such detoxification methods are also adopted in plant system during Cd toxicity in plants in presence of $\mathrm{Si}$ (Chen et al., 2000; Liang et al., 2005). Silicon is to enhance nutrient accretions by augmenting root activity (Chen et al., 2011), increasing water uptake (Sonobe et al., 2010), and improving roots hydraulic conductance (Hattori et al., 2008). Ma et al. (2001) reported that $\mathrm{Si}$ is the only quasi-essential element, which showed no serious detrimental effects even if it accumulates excessively in plant tissues. However, it increases abrasiveness of foliage which acts as a key element in defense of grasses. Massey \& Hartley (2006) reported that higher levels of silica in grasses causes increased abrasiveness of leaves resulting into deterring feeding by voles. As a result the growth rates of juvenile and mature female voles both reduces, which occur due to the decreased absorption of nitrogen from the foliage. Prasad et al. (2005) noted that silicon is a driving element in the evolution of dental adaptations seen in mammalian grazers. They found that vole feeding in grasses further increases the levels of silica in leaves, signifying a dynamic feedback mechanism in between grasses and their herbivores grazers. Therefore, the use of $\mathrm{Si}$ in agricultural had become a new trend as for the sustainable crop production strategies (Etesami \& Byoung, 2018). The present study is to investigate the effect of differential $\mathrm{Si}$ accumulation among the upland and low land Indica rice varieties and their consequence on the nature of uptake and mobilization of other essential nutrients under different concentration of Si.

\section{Materials and Methods}

\subsection{Genotype used}

Twenty-two upland and lowland rice varieties were collected from Rice Research Station of Orissa University of Agriculture and Technology, Bhubaneswar, Odisha, India for the differential silicon uptake experiment. Among the twenty two selected 
verities, sixteen were upland varieties i.e. Annada, Annapurna, Badami, Ghanteswari, Jogesh, Jyotirmayee, Keshri, Khandagiri, Lalat, Lalitagiri, Pathara, Shankar, Subhdra, Udaygiri, Uphar, Varnaporva while the rest six were lowland varieties i.e. Jagbandhu, Manswini, Pratikhya, Rambha, Swarna, Swarna Sub-1.

\subsection{Plant materials and growth conditions}

Around 200 seeds of each variety were used for experimentation. They were firstly disinfected using mercury chloride $(0.1 \%)$ for one minute followed by treatment of $0.5 \%(\mathrm{w} / \mathrm{v})$ fungicide 'Bavistin' for $30 \mathrm{~min}$ with continuous shaking. The seed were rinsed several times and soaked in deionized water at room temperature for whole day. The experiment was conducted hydroponically using Yoshida's nutrient solution (Yoshida et al., 1976). After 5-days of germination, 30 uniform seedlings were transferred to $10 \mathrm{~cm}$ plastic cups containing $50 \mathrm{ml}$ of Yoshida's nutrient solution (YNS, pH 5.0). The YNS was renewed every 4 days interval and $\mathrm{pH}$ was maintain till the completion of the experiment.

\subsection{Silicon uptake treatments}

Each plastic cup with 30 seedlings was fortified with four different concentrations of silicon ( $\mathrm{Si}$ ) i.e. $0.5,1.0,1.5$ and $2.0 \mathrm{mM}$ along with control $(0 \mathrm{mM})$ in Yoshida solution. Diatomaceous earth (80-90\% opal, $\mathrm{SiO}_{2} \cdot \mathrm{nH}_{2} \mathrm{O}$ ), an organic source of $\mathrm{Si}$ was used as the source of silicon supplementation. The plants grew in chambers with natural light and $50 \%$ humidity. On $5^{\text {th }}$ day the seedlings were transferred to YNS and after establishment on $6^{\text {th }}$ day, the Si supplementation was provided. After 10 and 20 days of treatment, three seedlings from each treatment of each variety were selected at random basis to measure the root and shoot growth. After 30 days of experiment, the samples were harvested and dried further to estimate the silicon content.

\subsection{Plant growth study}

Growth parameters of all twenty-two varieties in different concentration were recorded and analyzed. The root-shoot growths were measured 10 days after treatment (10 DAT) and 20days after treatment (20 DAT) application. The relative shoot and root growth compared to control conditions was calculated using following formula

Length of shoot or root under treatment

Relative growth $(\%)=\frac{}{\text { Length of shoot or root under Control }} \times 100$

\subsection{Estimation of silicon content}

After 30 days grown in hydroponic culture, samples of different varieties of each treatment were collected and dried in oven at $70^{\circ} \mathrm{C}$ for three days and powered for Si-estimation. For $\mathrm{Si}$ estimation, the samples were first digested and measured the $\mathrm{Si}$ content colorimetrically. Tissue analyses was done through digestion of powdered plant material $(0.1 \mathrm{~g})$ by autoclavedinduced alkali digestion to release the various forms of silicon (mono and poly silicates) and quantified through colorimetric molybdenum blue method (Wei-min et al., 2005). About $1 \mathrm{ml}$ of digested sample was transferred further into a $50 \mathrm{ml}$ polyethylene tube with addition of $30 \mathrm{ml}$ of $20 \%$ acetic acid and $10 \mathrm{ml}$ ammonium molybdate (54 g/l, $\mathrm{pH} 7.0)$. Further, the solution was shaken thoroughly and kept for $5 \mathrm{~min}$. and then addition $5 \mathrm{ml}$ of $20 \%$ tartaric acid and $1 \mathrm{ml}$ reducing solution. The reducing solution consisted of solution A ( $2 \mathrm{~g}$ of $\mathrm{Na}_{2} \mathrm{SO}_{3}$ and $0.4 \mathrm{~g} 1$-amino2-naphthol-4-sulfonic acid in $25 \mathrm{ml}$ of doubled distilled water) and solution $\mathrm{B}\left(25 \mathrm{~g}\right.$ of $\mathrm{NaHSO}_{3}$ in $200 \mathrm{ml}$ of doubled distilled water), and finally adjusted to $250 \mathrm{ml}$ with doubled distilled water. The volume was made up to $50 \mathrm{ml}$ with $20 \%$ acetic acid. The absorbance was taken at $650 \mathrm{~nm}$ under UV/Vis-Spectrophotometer (LAMBDA 365, Perkinelmer) after $30 \mathrm{~min}$. The silicon was calculated with the help of standard calibration curve.

\subsection{Atomic Absorption Spectroscopic (AAS) analysis}

The dried ground plant material $(0.5 \mathrm{~g})$ was digested with di-acid mixture of nitric acid and sulphuric acid used in 4:1 ratio. The samples were digested over a hot plate at $80^{\circ} \mathrm{C}$ for 1 hour. After the acid digestion, the samples ash were cooled to room temperature and scrapped with spatula dissolved in $5 \mathrm{ml}$ double distilled water. The $5 \mathrm{ml}$ mixture was filtered using Whatman filter paper and an aliquot was diluted to be used in AAS analysis. The rice samples were analyzed for $\mathrm{P}, \mathrm{K}, \mathrm{Ca}, \mathrm{Mg}, \mathrm{Fe}, \mathrm{Mn}$ and $\mathrm{Cu}$ concentration using atomic absorption spectrophotometer (iCE ${ }^{\mathrm{TM}}$ 3300 AAS. Thermofisher, Germany).

\subsection{Energy Dispersive X-Ray Spectroscopy (EDX)}

Scanning electron microscopy (SEM) coupled to EDX Spectroscopy was used for characterizing and mapping the relative elemental component in leaf surface of rice. The leaves were cut into small square piece $\left(1 \mathrm{~cm}^{2}\right)$ and placed exposing the abaxial surface of leaf on stubs sprayed with thin layer (1.5$3.0 \mathrm{~nm}$ ) of gold coating and system operation at voltage of $20 \mathrm{KV}$ (Ensikat et al., 2010). SEM-EDX micrographs were obtained using Field Emission Gun-SEM (JEOL JSM-7600F FEG-SEM).

Journal of Experimental Biology and Agricultural Sciences http://www.jebas.org 
Table 1 Germination percentage and length of 5-day old vigorous seedling used in Si uptake screening experiment.

\begin{tabular}{|c|c|c|c|}
\hline \multirow{2}{*}{$\begin{array}{l}\text { Varieties } \\
\text { used }\end{array}$} & \multirow{2}{*}{$\begin{array}{c}\text { Germination } \\
\text { percentage }(\%)\end{array}$} & \multicolumn{2}{|c|}{ Seedling length (Mean \pm SD) } \\
\hline & & Shoot $(\mathrm{cm})$ & Root $(\mathrm{cm})$ \\
\hline Annada & 80 & $2.8 \pm 0.7$ & $1.5 \pm 1.1$ \\
\hline Annapurna & 95 & $1.3 \pm 0.1$ & $0.7 \pm 0.5$ \\
\hline Badami & 100 & $3.1 \pm 0.1$ & $1.4 \pm 0.1$ \\
\hline Ghanteswari & 100 & $3.3 \pm 0.1$ & $2.4 \pm 0.6$ \\
\hline Jagbandhu & 95 & $2.9 \pm 0.3$ & $1.9 \pm 1.2$ \\
\hline Jogesh & 95 & $2.1 \pm 0.1$ & $1.6 \pm 0.7$ \\
\hline Jyotirmayee & 100 & $1.4 \pm .05$ & $0.9 \pm 0.3$ \\
\hline Keshri & 100 & $3.9 \pm .04$ & $2.9 \pm 0.8$ \\
\hline Khandagiri & 85 & $1.6 \pm .07$ & $2.0 \pm 1.4$ \\
\hline Lalat & 90 & $2.8 \pm 0.3$ & $1.5 \pm 0.4$ \\
\hline Lalitagiri & 95 & $1.5 \pm 0.1$ & $0.9 \pm 0.3$ \\
\hline Manswini & 90 & $2.3 \pm 0.1$ & $2.4 \pm 1.3$ \\
\hline Pathara & 95 & $2.3 \pm 0.1$ & $2.4 \pm 0.7$ \\
\hline Pratikhya & 100 & $4.1 \pm 0.6$ & $2.7 \pm 1.1$ \\
\hline Rambha & 85 & $2.2 \pm 1.4$ & $1.1 \pm 0.9$ \\
\hline Shankar & 90 & $3.3 \pm 0.4$ & $1.3 \pm 0.2$ \\
\hline Subhdra & 95 & $1.7 \pm 0.1$ & $1.3 \pm 0.5$ \\
\hline Swarna & 100 & $3.1 \pm 0.4$ & $2.5 \pm 0.7$ \\
\hline Swarna Sub-1 & 100 & $3.1 \pm 0.3$ & $3.1 \pm 0.4$ \\
\hline Udaygiri & 95 & $1.9 \pm 0.1$ & $1.2 \pm 0.6$ \\
\hline Uphar & 90 & $3.4 \pm 0.6$ & $3.6 \pm 0.9$ \\
\hline Varnaporva & 100 & $1.5 \pm 0.9$ & $1.4 \pm 0.9$ \\
\hline
\end{tabular}

Data are means of three replicates \pm SD

\subsection{Statistical analysis}

All analyses were carried out in triplicates. The experiment was set up in a randomized block design (RBD) and the experimental data obtained were subjected to statistical analysis by adopting Fisher's method for analysis of variance. The level of significance used in ' $F$ ' test and the Critical difference $(C D)$ values calculated were at 0.05 significance level $(\mathrm{p}<0.05)$. All graphs were presented with relative standard deviation as error bars.

\section{Result and Discussion}

Rice is a classic example of Si-accumulating species as they can accumulate Si up to $10 \%$ of shoot dry weight. Tamai \& Ma (2003) compared the whole gramineous species including wheat, triticale, sorghum, rye, maize and barley for their Si-uptake ability during a period of 24 hours under the same condition and observed that the $\mathrm{Si}$ uptake by rice roots was much higher than any other gramineous species. However, silicon content in the plant varies greatly among the plant species. Genotypic variations and its understanding are critical as it alters the quantity of $\mathrm{Si}$ accumulated. The alteration in Si accumulation indirectly affects the degree of resistance towards chemical stresses and adversely affects nutrient mobilization in crop species. Ma et al. (2007) reported that the presence of two Si transporter genes naming Low silicon rice 1 and 2 ( Lsil and Lsi2) expressed highly in case of both japonica and indica species. They also highlighted the variation in their abundance as the core reason of genetic variation in rice species. Among the 22 studied genotypes, the germination ability, root and shoot growth were found to be varied in different concentration of Si (Table 1-3). Vigorously growing 5-days old germinated seedlings of each variety were used for the study. All of the indicia genotypes showed higher relative growth with increase in external $\mathrm{Si}$ supplementation, primarily in the concentration range of $1.0-1.5 \mathrm{mM}$, signifying the optimum $\mathrm{Si}$ concentration for the growth of Indica rice genotypes. Above $1.5 \mathrm{mM} \mathrm{Si}$, some of the tested genotypes exhibited depressing growth rate. Significant difference was recorded amongst the shoot growth rate of each cultivar with change in amount of $\mathrm{Si}$ added at 10days after treatment (Table 2). A prominent relative growth change was observed in shoot growth, but roots don't signify much variation. The maximum relative shoot growth was represented by the vars. Ghanteswari, Jyortirmayee, Pratikhya and Swarna after 10-days treatment. Other varieties like Annada, Annapurna, Keshri, Lalat, Lalitagiri, Manswini, Pathara, Rambha, Shankar, Swarna Sub-1, Uphar showed modest growth followed by Badami, Jagbandhu, Jogesh, Khandagiri, Shubdhra, Udaygiri and Varnaporva verities with lowest relative growth rate. But, after 20 days treatment of silicon (Table 3), both relative shoot growth and root growth rate compared to control were significantly different. Among all varieties used, variety Ghanteswari, Pratikhya and Swarna continued to show higher relative shoot growth rate, while other variety Badami, Jagbandhu, Jogesh, Khandagiri and Shubdhra sustained as low relative growth varieties. The remaining varieties were showing moderate growth rates under varying $\mathrm{Si}$ concentration. It was difficult to categorize all these varieties into high, moderate and 
Table 2 Effect of different silicon treatments on relative growth percentage of shoot and root in comparison to control seedlings after 10-days of treatment.

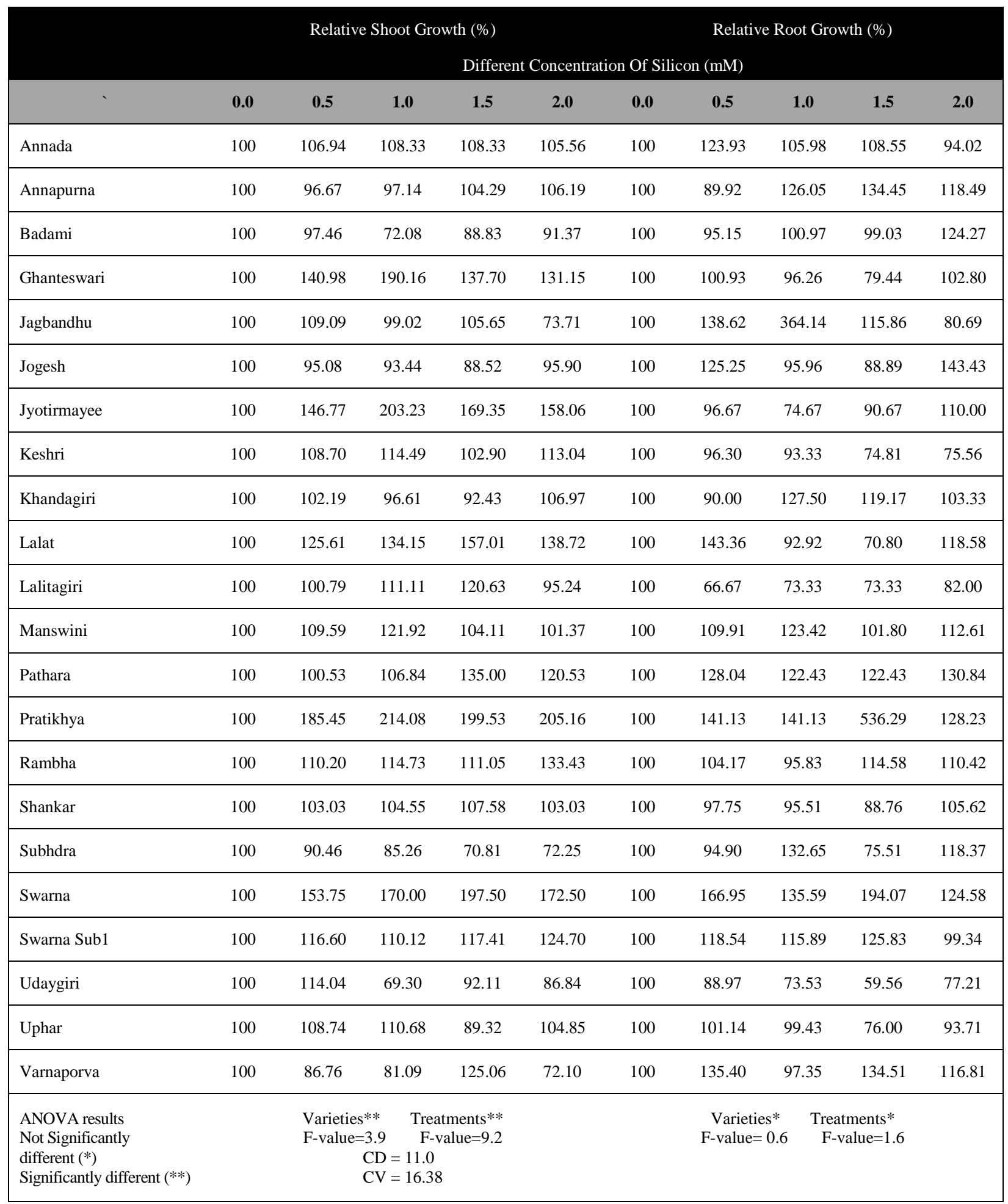

[Note- Data was subjected to two ways ANOVA at $p<0.05$ and results are presented above with Critical Difference (CD) and Coefficient of Variation $(\mathrm{CV})$.] 
Table 3 Effect of different silicon treatments on mean relative growth percentage of shoot as well as root in comparison to control seedlings after 20-days of treatment.

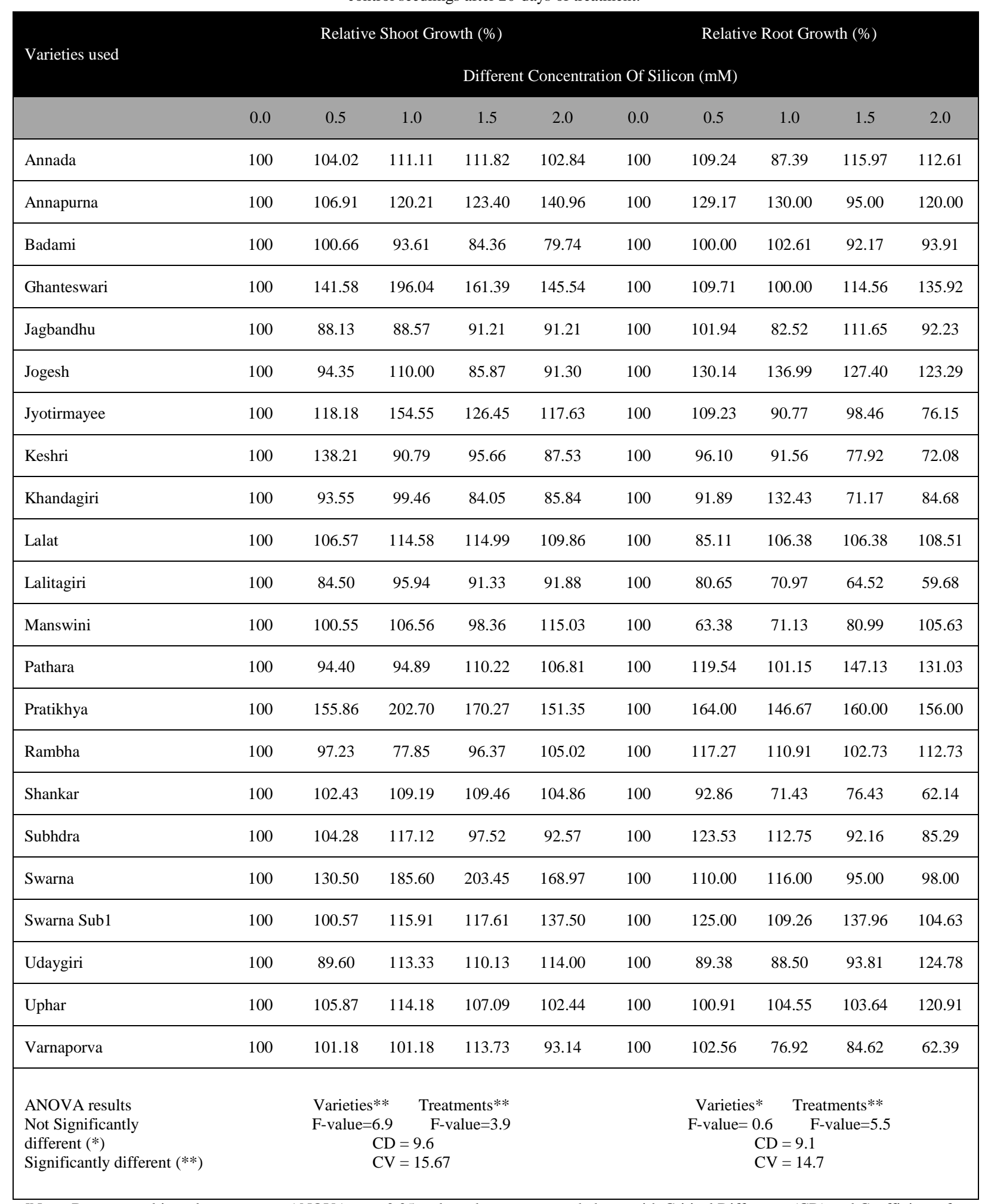

[Note- Data was subjected to two ways ANOVA at $p<0.05$ and results are presented above with Critical Difference (CD) and Coefficient of Variation $(\mathrm{CV})$.] 


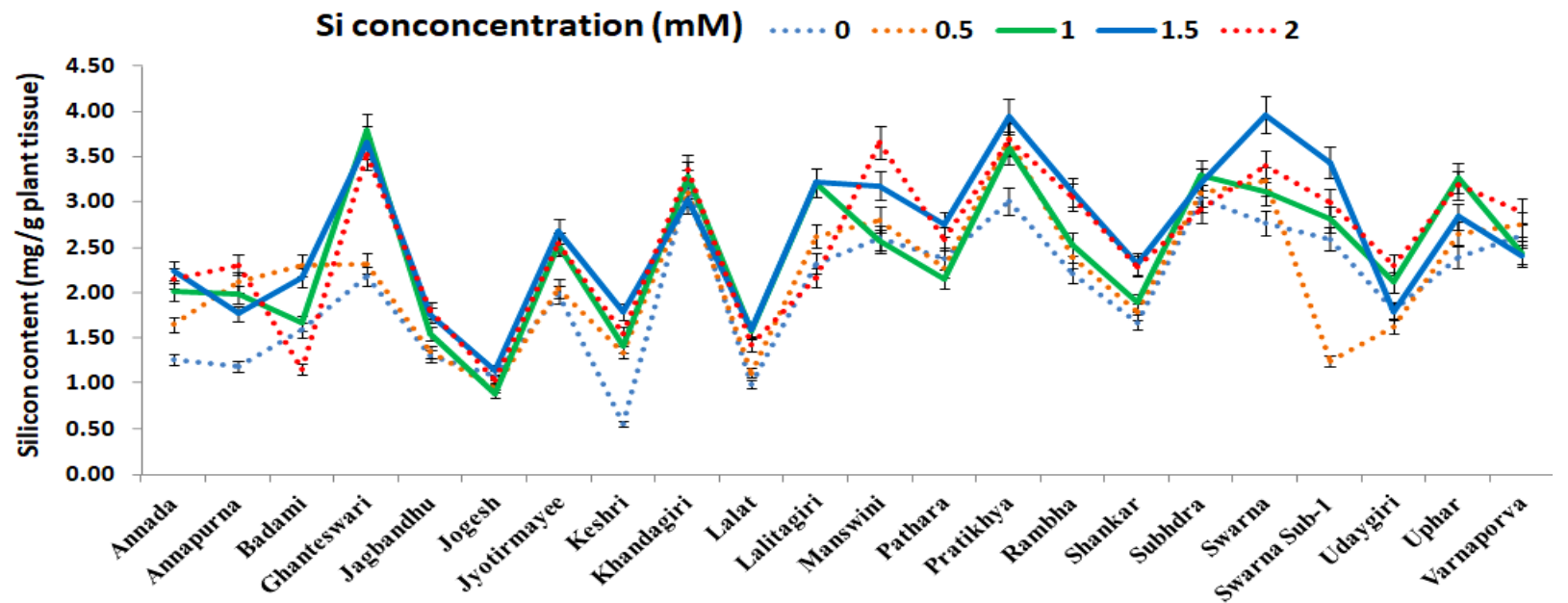

Figure 1 Impact of different silicon treatment on mean silicon accumulation of 22 varieties of indica rice represented as mg Si/g plant tissue. Data are means \pm RSD (relative standard deviation, $n=3$ ) as error bars. Data showed significant differences between treatments $\mathrm{p}<0.05$ according to Fisher's protected LSD test ( $\mathrm{p}$-value $=<.001, \mathrm{LSD}=4.94)$.

low uptake groups based on only relative shoot growth rate. So, the amount of $\mathrm{Si}$ accumulated was also quantified to get a clear idea of the nature of uptake of these varieties as positive correlation was expected between relative growth rate and $\mathrm{Si}$ deposition. Each treatment harvested was estimated for its $\mathrm{Si}$ content by blue ammonium molybdate colorimetric method. Weimin et al. (2005) proposed a reliable method for rapid determination of $\mathrm{Si}$ content in rice using a RIL population (cross Zhenshan 97B / Milyang 46) by adopting high-temperature alkaline fusion method for digestion. A linear and positive trend was obtained during silicon estimation study, which was similar to the trend obtained in relative shoot growth rate study. The highest Si deposition was obtained in $1.0-1.5 \mathrm{mM}$ Si treatments which are parallel to the pattern of maximum relative growth rate (Figure1). The present study specifies and confirms a direct positive correlation between the silicon deposition and relative growth in rice. But, in few varieties such as Annapurna, Khandagiri, Manaswini, Udaygiri, and Varnaporva even showed higher silicon accumulation till $2 \mathrm{mM}$ external Si supply. Hence, by considering both relative shoot growth rate and amount of silicon accumulated by the each variety, they are categorized as into three groups and designated as- 'high-accumulators', 'moderate-accumulators' and 'low-accumulators' of silicon (Table 4).

Nutrient management in rice is an essential criterion for improving the production and productivity of crop. Tamai \& Ma (2008) reported the effects of silicon on rice growth and production under field conditions by developing a low silicon mutant. They observed that at a later growth stage of rice, the wild
Table 4 Based on the data of mean relative shoot growth percentage (Table $2 \& 3$ ) and mean silicon accumulation (Figure-1) in 22 rice varieties, they are categorized into three silicon differential accumulators group. Two varieties (one upland and one lowland) were selected from each group for further nutrient load analysis.

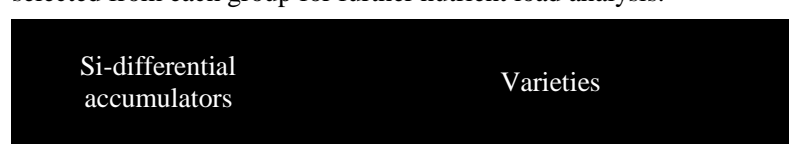

High Si-accumulators

var. Ghanteswari, var. Swarna, var. Swarna Sub-1

var. Annada, var. Annapurna, var. Jyotirmayee, var. Keshri, var. Lalat, var. Lalitagiri, var. Manswini, var. Pathara, var. Pratikhya, var. Udaygiri, var. Uphar

Moderate

var. Badami, var. Jagbandhu, var. Jogesh, var. Khandagiri, var. Rambha,

Low Si-accumulators var. Shankar, var. Shubdhra, var. Varnaporva

type showed slightly higher plant height and shoot dry weight than the mutant one. They estimated that the silicon deposited in the shoots during harvest of both the wild type and mutant and reported as $4.14 \%$ and $0.22 \%$ of the dry weight basis, respectively. They suggested that's why the plant height and shoot dry weight was increased in mutant. They also explained that beneficial effects of silicon are underestimated in most studies as the effect of $\mathrm{Si}$ on plant growth are more pronounced under stress conditions and is much emphasized, while its effects 
were left unnoticeable under non-stressed conditions. Cuong et al. (2017) observed that optimum dose of silicon fertilizer (329 $\mathrm{Kg} / \mathrm{hm}^{2} \mathrm{SiO}_{2}$ ) can maximize the grain yield $3716 \mathrm{Kg} / \mathrm{hm}^{2}$ and enhanced the nutrient uptake of N, P, K and Si significantly. Si build up in leaf surface results into increased shoot-root biomass, reduced transpiration, increased chlorophyll synthesis, maintain homeostasis and osmoregulation inside cells ultimately influencing photosynthesis and plant growth and production. Therefore, essentially to understand the effect and consequence of genotypic differential Si-accumulation on the mobilization of other nutrient ions in rice, 22 varieties were categorized into three groups as high, medium and low accumulators. One variety of each group, (Table 4) one belonging to upland and other from lowland Indica rice were selected as representative of group and further experimented for studying the interaction of silicon and mobilization of macronutrients ( $\mathrm{P}, \mathrm{K}, \mathrm{Ca}$ and $\mathrm{Mg}$ ) and micronutrients $(\mathrm{Fe}, \mathrm{Mn}$ and $\mathrm{Cu})$. The three upland varieties viz., Ghanteswari (High-accumulator), Jyotirymee (Moderateaccumulator), Badami (Low-accumulator) and three lowland varieties viz., Swarna (High-accumulator), Pratikhya (Moderateaccumulator) and Jagbandhu (Low-accumulator) were used for Si and other nutrient interaction study. The nutrient mobilization trend of micro- and macronutrients were studied in 'basic nutrient solution (Yoshida, $\mathrm{pH}=5$ )' under varying silicon concentration in comparison to control. The other nutrients were quantified through the Atomic absorption spectroscopy (AAS) technique widely used for determining traces of metals in any decomposed or hydrolyzed solid sample. The hydrolyzed solid sample is converted in aqueous aliquot and diluted to aspirate the metal analyte into an air-acetylene flame, causing evaporation of the solvent and vaporization of the free metal atoms.

The first macronutrient focused was Phosphorous (P), which is an important nutrient necessary for plant growth and can limit rice productivity due to its low availability in soil. Phosphorous amount was estimated through atomic absorption spectrophotometer (AAS) in all the 30 samples of six varieties with different $\mathrm{Si}$ concentration (i.e. five treatments of each variety). Based on quantification results (Figure-2a), it was observed that phosphorous has optimistic association with the increase in $\mathrm{Si}$ concentration. The high and moderate accumulator's showed increase in P uptake among the tested varieties, Ghanteswari and Pratikhya showed improved uptake till $1.0 \mathrm{mM}$ concentration of $\mathrm{Si}$ and subsequently declined. Whereas, variety Swarna and Jyotirmayee showed continuous higher uptake even up to $2.0 \mathrm{mM}$ external application silicon. However, the low accumulator varieties such as 'Badami' and 'Jagbandhu' did not show any regular trend of $\mathrm{P}$ deposition. The present study showed that there was a genotypic differential for $\mathrm{Si}$ - accumulation in rice varieties used. Ma \& Takahashi (1990) reported that Si fertilizer can improve plant $\mathrm{P}$ utilization by escalating both $\mathrm{P}$ content of rice and enhancing phosphate fertilizer efficiency, but the study
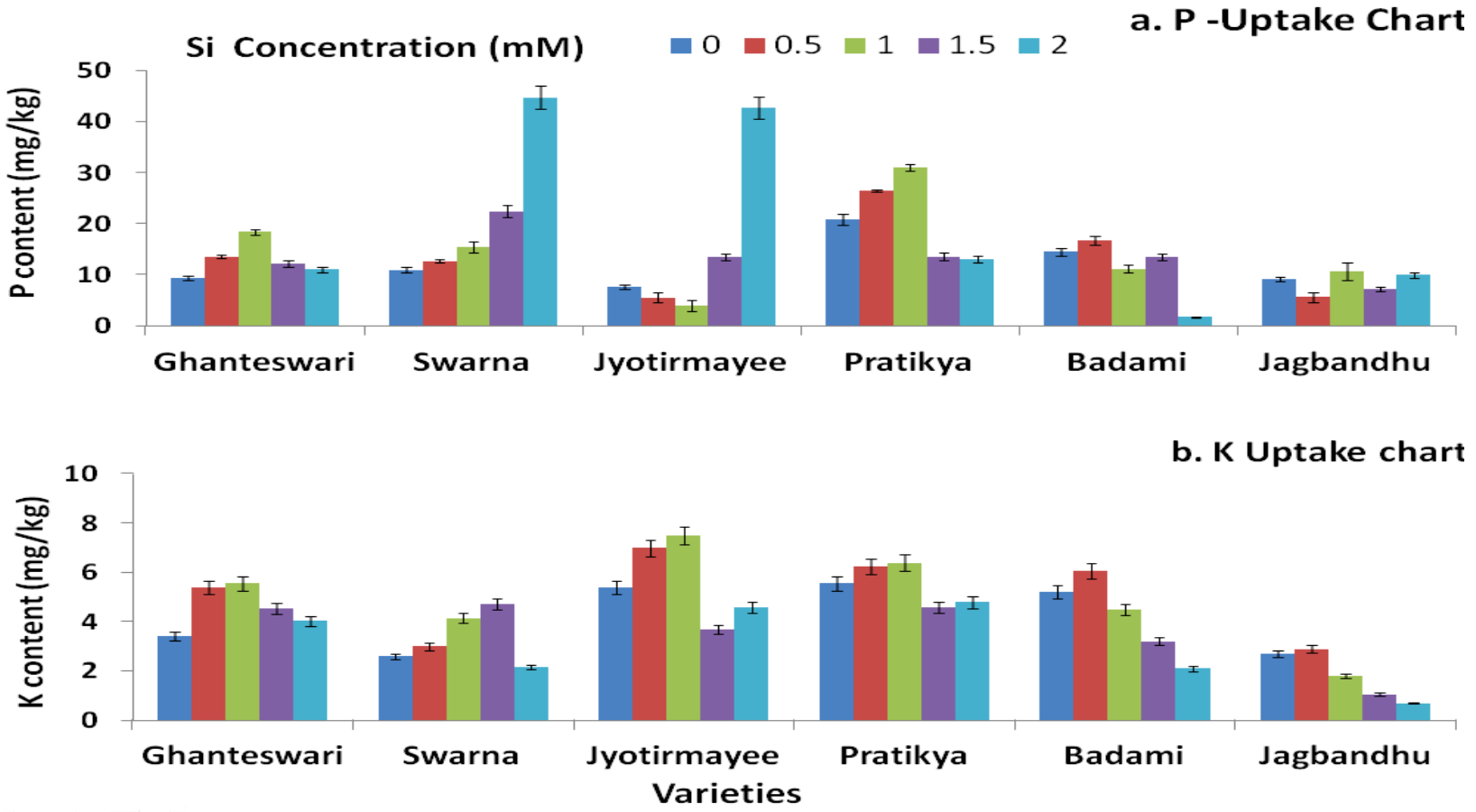

Figure 2 Effect of different silicon treatment on nutrient load of macronutrient Phosphorous $(\mathrm{P})$ and Potassium $(\mathrm{K})(\mathrm{expressed} \mathrm{in} \mathrm{mg} / \mathrm{kg})$ in 6 selected Si-differential accumulator varieties. Data are means \pm RSD (relative standard deviation, $n=3$ ) as error bars. Results for $\mathrm{P}$ were not significantly different and for K results were significantly different between treatments at $\mathrm{p}<0.05(=0.0034)$ according to Fisher's protected LSD test. 
was conducted in different P levels in nutrient media. Agostinho et al. (2017) reported that there was significant variation of rice grain yield and $\mathrm{Si}$ accumulation on application of varying $\mathrm{P}$ concentration through pot culture experiments. However, they proposed that $\mathrm{P}$ and $\mathrm{Si}$ in the soil can creates a synergistic effect on soil having $\mathrm{Al}, \mathrm{Mn}$, and $\mathrm{As}(\mathrm{P}<0.01)$, but not in growth of plant and $\mathrm{P}$ uptake.

The present study also emphases on the effect of genotypic differential uptake of silicon in presence of potassium (K), which is essential for maintenance of osmotic pressure and homeostatic of plant cell. In case of $\mathrm{K}$, all the six varieties showed augmented accumulation of $\mathrm{K}$ with the increase in $\mathrm{Si}$ concentration (Figure $2 \mathrm{~b}$ ). The result also suggests that increment in $\mathrm{K}$ uptake was supported only up to optimum level of $\mathrm{Si}(1.0-1.5 \mathrm{mM})$ in plant tissue, after which it declined. Hence, it is opinion that $\mathrm{Si}$ show affirmative correlation with enhancement in the $\mathrm{K}$ uptake in rice. Chen et al. (2016) applied $\mathrm{Si}$ to K-deficient $(0.5 \mathrm{Mm})$ sorghum seedlings for 15 days and found that $\mathrm{K}^{+}$content in xylem sap was significantly increased and osmotic potential of xylem sap was decreased. They explained that the major reason for Siinduced improvement was enhanced $\mathrm{K}^{+}$concentration in xylem sap, which increases the osmotic gradient and hence xylem hydraulic conductance. However, they reported no effect on sorghum growth by $\mathrm{Si}$ application $(1 \mathrm{mM})$ under control conditions. Also, the growth and water status were reduced by Kdeficient stress, but $\mathrm{Si}$ suppementation significantly alleviated these decreases in parameters.
In another experiment, the addition of $\mathrm{Ca}$ with silicon showed a variation with regard to upland and lowland varieties (Figure 3a). In case of $\mathrm{Ca}$ interaction with silicon, the upland varieties Ghanteswari, Jyotirmayee and Badami showed positive link with silicon accumulation. The increment in $\mathrm{Ca}$ uptake can be seen up to $1.0 \mathrm{mM} \mathrm{Si}$ in all the genotypes, while in variety Jyotirmayee further enhanced uptake up to $2.0 \mathrm{mM}$ silicon application was reported. But, the lowland varieties like Swarna, Pratikhya, and Jagbandhu showed a disturbed $\mathrm{Ca}$ uptake trend with increase in $\mathrm{Si}$ concentration. Calcium uptake trend seems to be negatively correlated with Si uptake. The impact of silicon on growth and nutrient status of rice plants grown under different concentrations of zinc regimes has been reported (Mehrabanjoubani, 2014). They reported that silicon application increased with $\mathrm{Ca}^{2+}, \mathrm{K}^{+}, \mathrm{P}$ and B contents in plants under $50 \mu \mathrm{g} / \mathrm{l} \mathrm{Zn}$. Marxen et al. (2016) reported that the total uptake of $\mathrm{P}$ was increased and decreased of $\mathrm{Ca}$ due to the high $\mathrm{Si}$ application in rice. The present study showed the contradictory trend among the lowland and upland varieties and suggesting the variation in the need of nutrient in the rice crop based on their growth conditions. Quiet similar interaction pattern (Figure 3b) was observed in case of Magnesium ( $\mathrm{Mg}$ ), i.e. the upland varieties showed increased $\mathrm{Mg}$ uptake under low levels of silicon application up to $1.0 \mathrm{mM}$. Above $1.0 \mathrm{mM}$ silicon application, the lowland varieties showed continuous decrease of $\mathrm{Mg}$ deposition. Therefore, it is concluded that higher silicon deposition in rice has a negative effect on $\mathrm{Mg}$ uptake. Further, Korkmaz et al. (2018) studied the effect of different concentration of $\mathrm{Si}(0,0.5,1.0,2.0 \mathrm{mM})$ on tomato plant
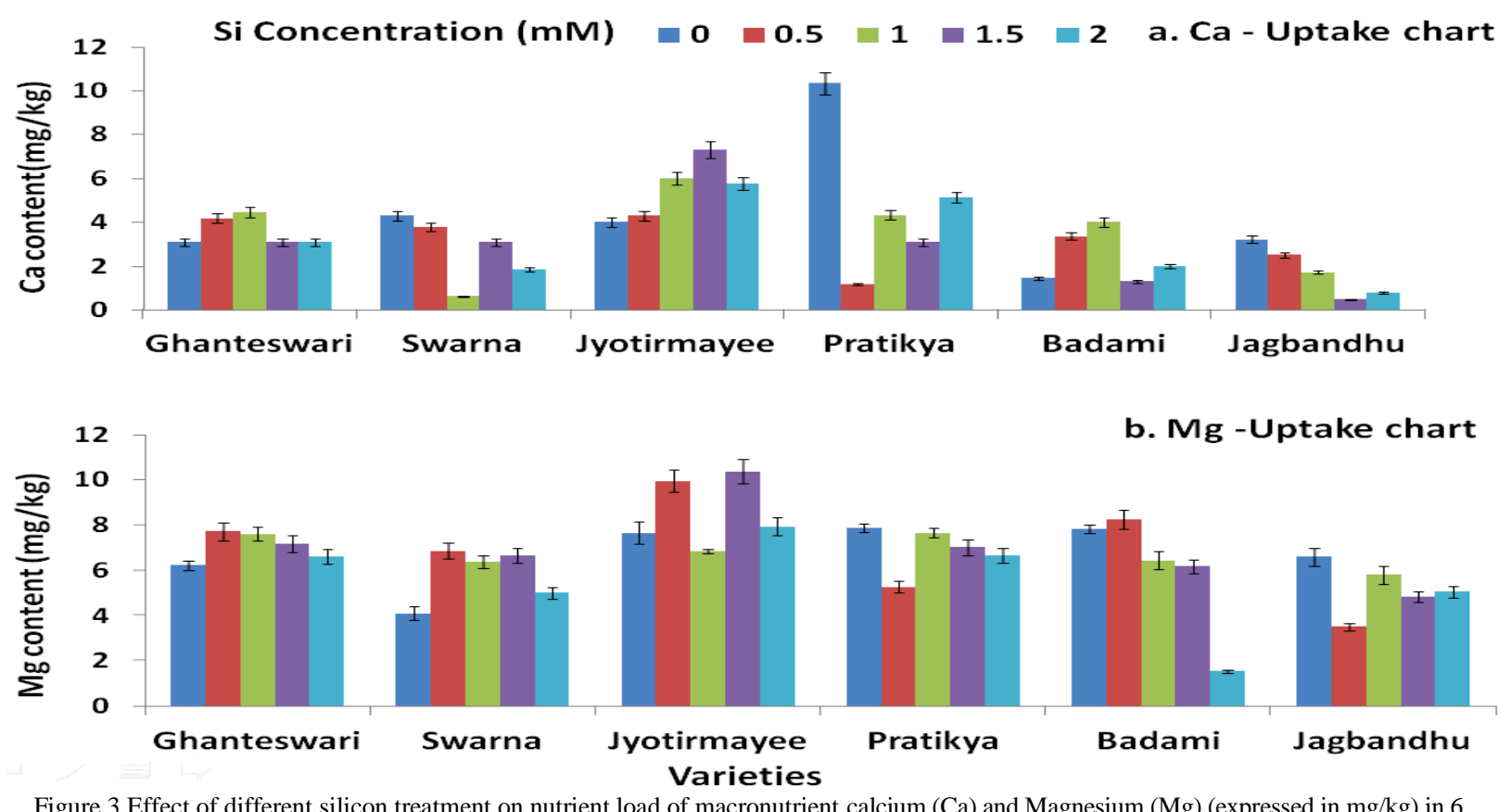

Figure 3 Effect of different silicon treatment on nutrient load of macronutrient calcium $(\mathrm{Ca})$ and Magnesium $(\mathrm{Mg})(\operatorname{expressed~in~} \mathrm{mg} / \mathrm{kg})$ in 6 selected Si-differential accumulator varieties. Data are means \pm RSD (relative standard deviation, $n=3$ ) as error bars. Results for both $\mathrm{Ca}$ and $\mathrm{Mg}$ were not significant different between treatments, but were significantly different between varieties at $\mathrm{p}<0.05$ according to Fisher's protected LSD test. 
under salt stress and reported no significant ( $p>0.05)$ change in $\mathrm{Ca}$ and $\mathrm{Mg}$ concentration in leaves. However, Horuz \& Korkmaz (2014) previously reported that Si fertilization improved the ratios of $\mathrm{K} / \mathrm{Na}, \mathrm{Ca} / \mathrm{Na}, \mathrm{Mg} / \mathrm{Na}$ and $\mathrm{P} / \mathrm{Na}$ in rice under salt stress and also that it decreased the damage caused salt.

Micronutrients are also essentially important in nutrient management system as involved in many biological processes as catalyst. They are not generally incorporated in fertilization programs, but crops even have prescribed recommendation for micronutrients. Silicon was not considered as essential nutrient in plants, but performs several beneficial activities in its accumulating species. The present study was to know the interaction of silicon with microcronutrient like manganese $(\mathrm{Mn})$, iron $(\mathrm{Fe})$ and copper $(\mathrm{Cu})$. The result showed that silicon accumulation was optimum and positive association with all the micronutrients by encouraging there utilization (Figure 4a). However, in case of $\mathrm{Fe}$ the trend differs with different $\mathrm{Si}$ accumulating group of rice (Figure $4 b$ ). The high and moderate Si accumulators showed better and enhanced utilization of $\mathrm{Fe}$ with increasing silicon deposition. Furthermore, the upland varieties showed increment up to optimum Si $(1.0-1.5 \mathrm{mM})$ deposition, while the lowland varieties Swarna and Pratikya showed continuous increased uptake with silicon supplementation. The low accumulator of both
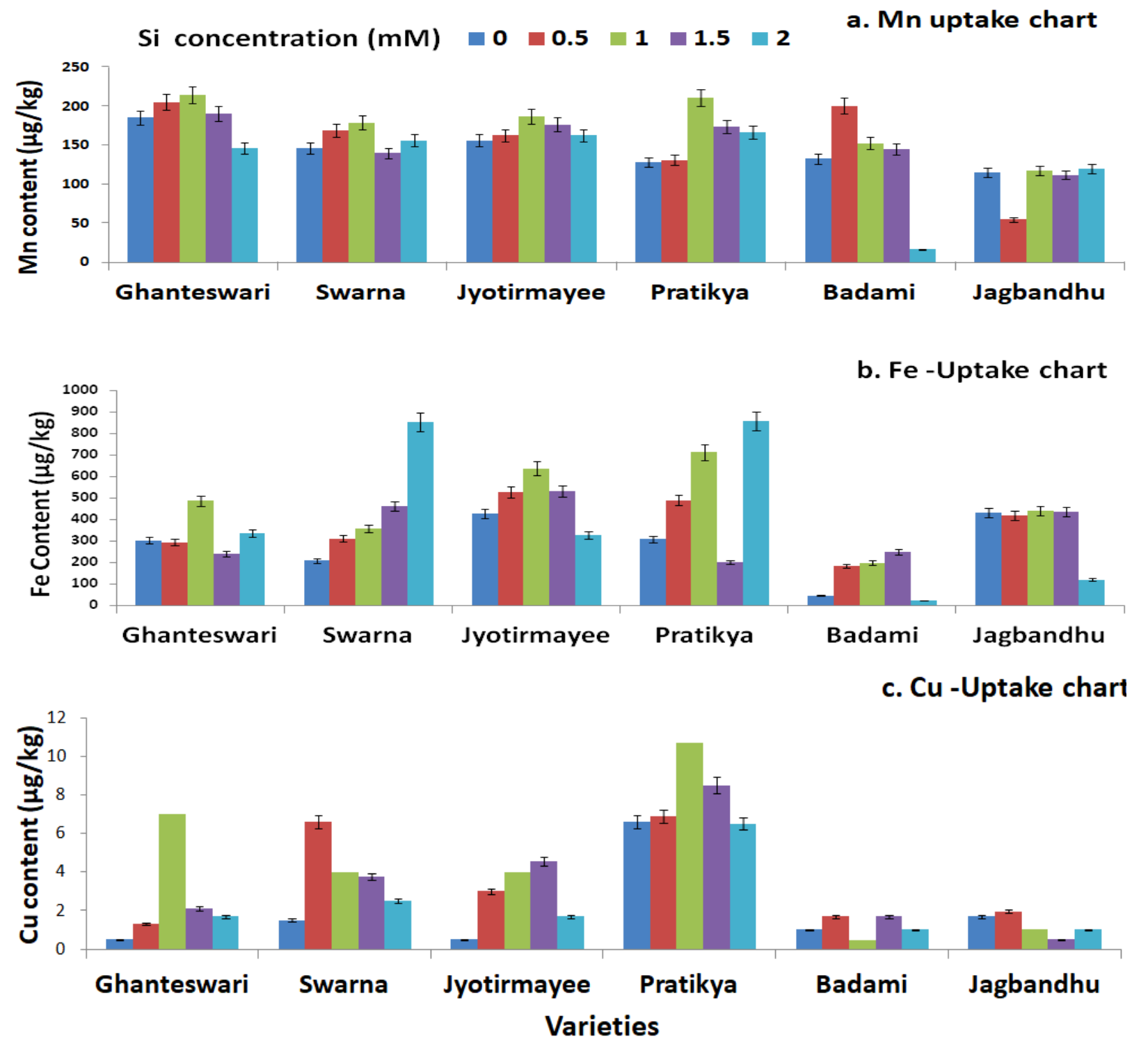

Figure 4 Effect of different silicon treatment on nutrient mobilization of micronutrient manganese ( $\mathrm{Mn})$, iron $(\mathrm{Fe})$ and copper $(\mathrm{Cu})$ (expressed in $\mu \mathrm{g} / \mathrm{kg}$ ) in 6 selected Si-differential accumulator varieties. Data are means \pm RSD (relative standard deviation, $\mathrm{n}=3$ ) as error bars. Results for all $\mathrm{Mn}, \mathrm{Fe}$ and $\mathrm{Cu}$ were significantly different between varieties at $\mathrm{p}<0.05$ according to Fisher's protected LSD test. 
upland (Badami) and lowland (Jagabandhu) varieties were not able to utilize $\mathrm{Fe}$ better from the nutrient media. Finally, the $\mathrm{Cu}$ interaction with silicon was observed and presented in Figure-4c and found close similarity with $\mathrm{Fe}$. It was also reported that high and moderate $\mathrm{Si}$ accumulator varieties showed better mobilization of $\mathrm{Cu}$ from nutrient solution. But, the low or poor silicon accumulator fails to deposit silicon in their cells and thus show very low rate of uptake of nutrients from media. Overall all micronutrients i.e. $\mathrm{Mn}, \mathrm{Fe}$ and $\mathrm{Cu}$ have enriched in plant tissue and establish a favorable link with Si. Majority of silicon and micronutrient interaction studies in rice were concentrated on the silicon induced alleviation effects of micronutrient and heavy metal toxicity ( $\mathrm{Mn}, \mathrm{Fe}, \mathrm{Cu}, \mathrm{Al}, \mathrm{Zn}, \mathrm{Cd}, \mathrm{Pb}$, As, etc.). All these studies reported the decrease in level of toxic micronutrient ions in their rich supply environment. HernandezApaolaza (2014) studied the physiological role of $\mathrm{Si}$ in micronutrients deficiency in cucumber under hydroponic system. He explained that the Si supply mitigates the symptoms of Fe deficiency under Fe-deficient condition, but this effect was not clear under $\mathrm{Zn}$ - or Mn-deficient conditions. He suggested that the Si actually interact with the metal distribution in the plant which results into diminishing the damage. Carrasco-Gil et al. (2018) reported that under Fe sufficiency conditions, Si supply increased in Fe root plaque formation. So, $\mathrm{Fe}$ acquisition strategies got activated and subsequently the rate of Fe translocation to the aerial parts. They also reported that under Fe deficiency, Si-accumulator plants absorbed Fe from the plaque more rapidly than $\mathrm{Si}$-accumulator plants. The present study represented the EDX maps of the nutrients present on the leaf surface (Figure-5). EDX map was developed to identify the change in accumulation of different macronutrient and micronutrient in leaf under silicon influence. It can't provide the clear idea of the rate of accumulation, still will be useful in providing the relative evidence of nutrient deposition. It was observed that the variety Ghanteswari grown in nutrient solution with or without $\mathrm{Si}$ showed differential accumulation of mineral with significant variation (Figure $6 \& 7$ ). The elemental spectrum of leaf surface was also presented in Figure-5, depicting the quantity and presence of other nutrients. With increase in the external application of $\mathrm{Si}$, the amount of silicon deposition was more in leaf tissues and also influencing the other enhanced uptake of nutrients like $\mathrm{K}$ and $\mathrm{Ca}$ (Figure-5). The plant grown without silicon showed concentration of carbon backbone as $42.53 \%$ and silicon concentration as $0.41 \%$. In plant grown with the addition of $1.0 \mathrm{mM}$ silicon supplementation, the concentration of carbon backbone was found to be $38.69 \%$ and silicon concentration as $11.8 \%$. Thus, we could conclude that the silicon contribute to the structural formation of leaf tissue providing strength, protection against penetration from pest and grazing animals.

In conclusion, considering the various studies conducted the present study concluded that 'silicon act differently based on the growth conditions of rice' (Figure 8). Under metal toxicity (Al, $\mathrm{Cd}$, As, $\mathrm{Mn}, \mathrm{Fe}, \mathrm{Zn}$, etc.) conditions in rice, silicon causes mitigation of harmful toxicity effects of metals. It basically alleviates the uptake of harmful metal ions and thus reduces the oxidative stress caused by them. Sometimes essential macronutrients such as $\mathrm{P}$ and $\mathrm{N}$ are applied in excess to the rice, resulting into negative consequences on growth and productivity. Silicon can also provide advantageous outcomes under such stress situations. It allow lower uptake of excess $\mathrm{P}$ and $\mathrm{N}$ and improve their utilization all along the whole rice plant. Thus reducing the injurious effects caused by excess fertilizers applications. All of these effects of silicon application under stress are enhanced in case of 'high $\mathrm{Si}$-accumulator varieties', whereas lowered if it's a 'low Si-accumulator'. While under unstressed conditions the effects of silicon supplementation is not much pronounced, however showed positive results in rice nutrient mobilization. The nutrient such as $\mathrm{P}$ and $\mathrm{K}$ showed higher uptake and better mobilization inside rice plant with silicon supplementation. Other essential macronutrients such as $\mathrm{Ca}$ and $\mathrm{Mg}$ also showed higher uptake, but results varies with the nature of rice. In case of the lowland varieties, $\mathrm{Ca}$ accumulation is lower with enhanced Si uptake. Opposite the above results, in upland varieties higher accumulation of $\mathrm{Ca}$ occurs with improved $\mathrm{Si}$ uptake. Micronutrient also reported to demonstrate better utilization and uptake under higher silicon accumulation. But, all these characters are highly influence by the genotypic differential silicon uptake nature of rice. More than the stress conditions, in unstressed state the genotypic differential $\mathrm{Si}$-uptake nature are essential to considered. The differential nature of rice decides the modification in rate of higher nutrient mobilization properties. As the property depends on rate of silicon accumulation, the higher the Si-uptake potential better is the nutrient mobilization property of a variety. Low silicon accumulating varieties showed unpredicted results in most of the cases even in presence of high silicon application. This study focused on identifying the relationship of genotypic difference in Si-uptake and its interaction with other nutrient in rice. Therefore, the nutrient absorption capacity of plant can be improved further and the nutrient deficient soil can also be effectively used for enhancing the productivity of rice. 


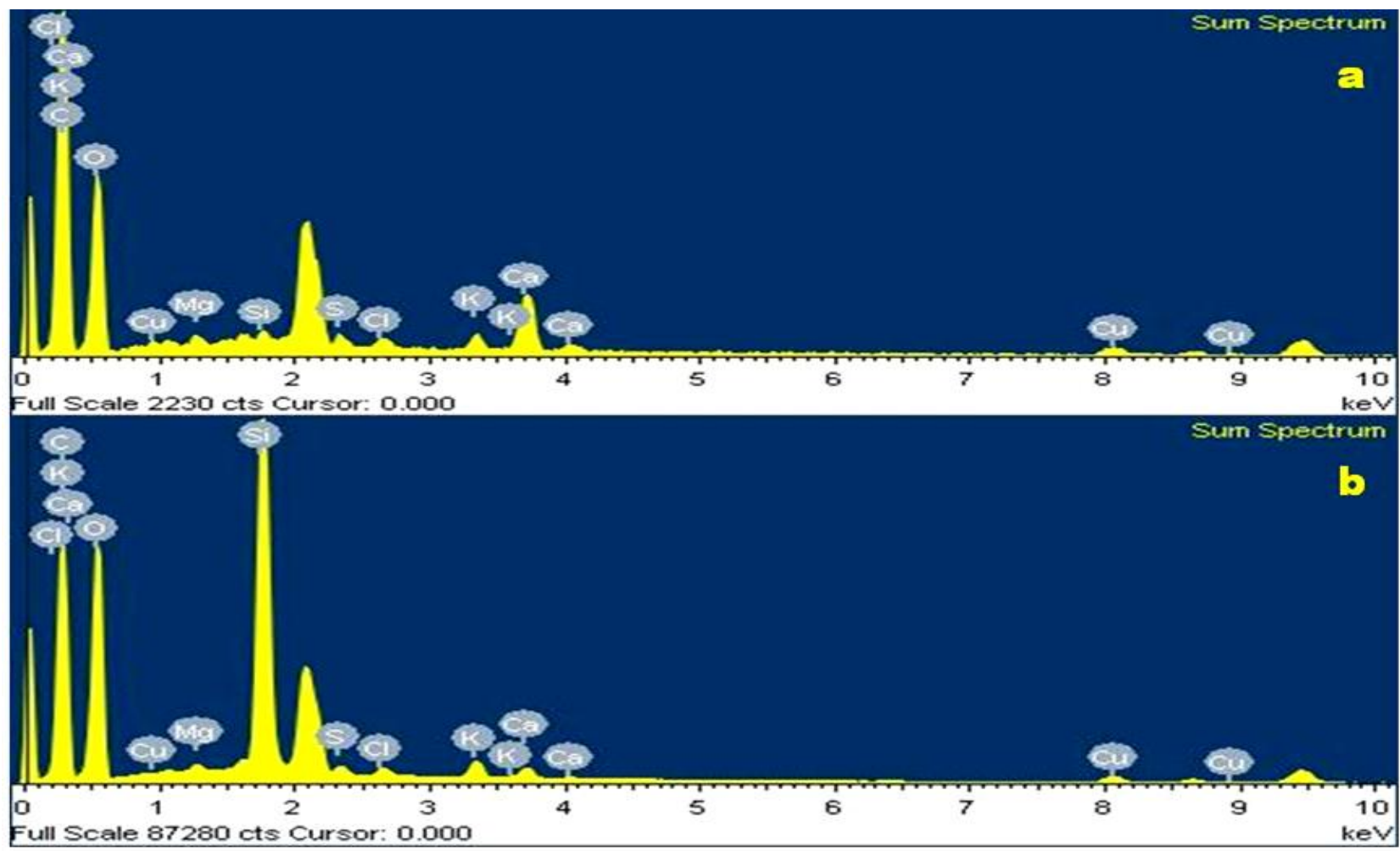

Figure 5. EDX Spectrum obtaied during EDX analysis of abaxial leaf surface of va. Ghanteshwari grown in a) -Si nutrient solution and b) $+\mathrm{Si}(1.0 \mathrm{mM})$ nutrient solution at $20 \mathrm{KV}$ voltage detecting the distribution of different elements $\mathrm{n}$ leaf surface.

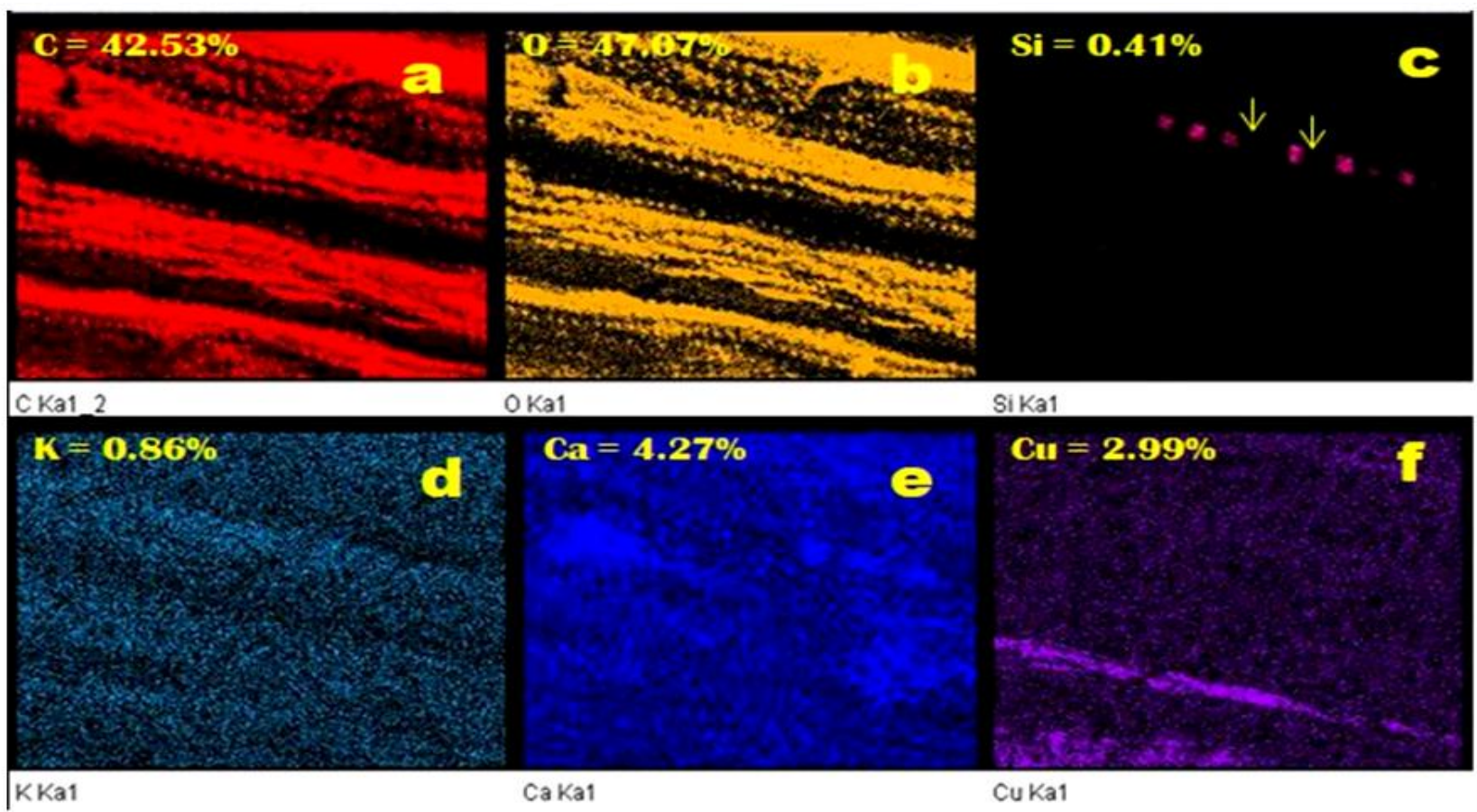

Figure 6. EDX element mapping of var.Ghanteswari leaf grown on nutrient solution with no added $\mathrm{Si}$. a) Carbon-C, b) Oxygen-O c) Silicon-Si, d) Potassium-K, e) Calcium-Ca, and f) Copper-Cu.

Journal of Experimental Biology and Agricultural Sciences http://www.jebas.org 


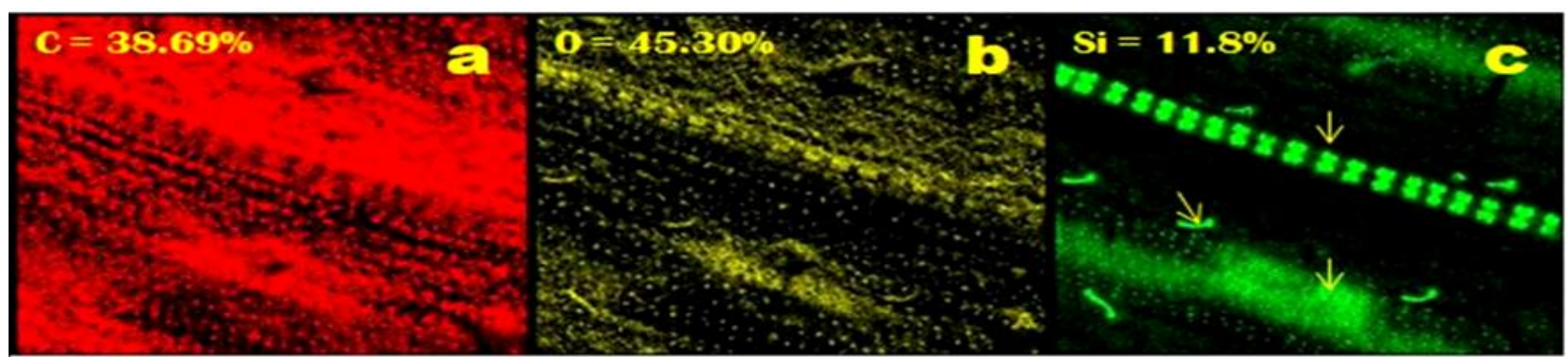

Si Ka1

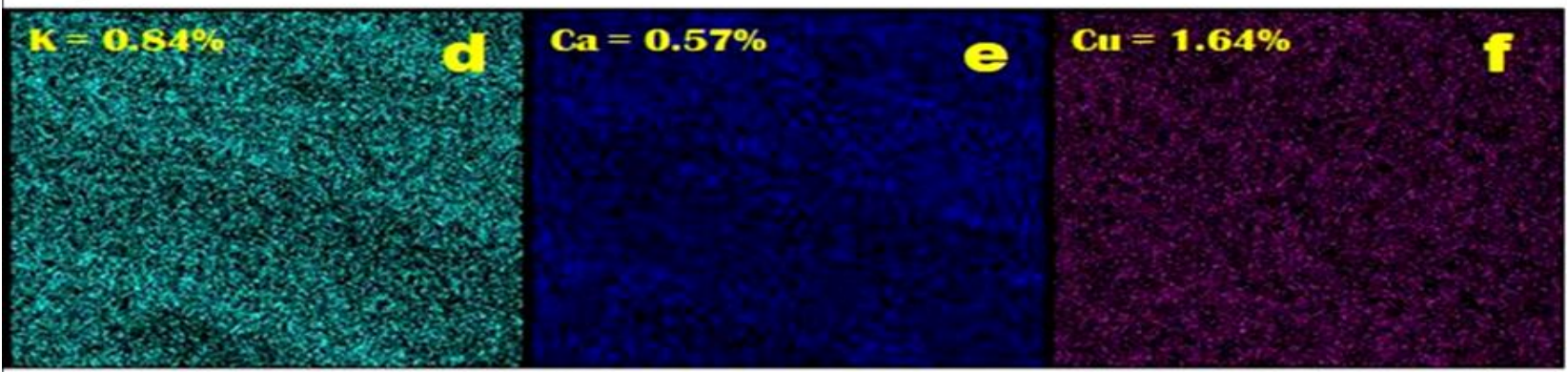

Figure 7. EDX elemental mapping of var.Ghanteswari leaf grown on nutrient solution with $1.0 \mathrm{mM}$ added Si. a) Carbon-C, b) Oxygen-O, c) Silicon-Si. d) Potassium-K, e) Calcium-Ca, and f) Copper-Cu.

\section{Under stressed}

Mitigate metal toxicity (AI, Cd, As, Mn, Fe, Zn, etc.)

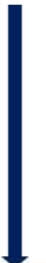

Lessen $P$ excess stress

(Decline in P uptake)

Reduce excess $\mathbf{N}$ stress (Improved N utilization)<smiles>[TeH]</smiles>

\section{s
ss}

\section{Legend:Decrease Increase}

\section{Si-induced Nutrient Mobilization}
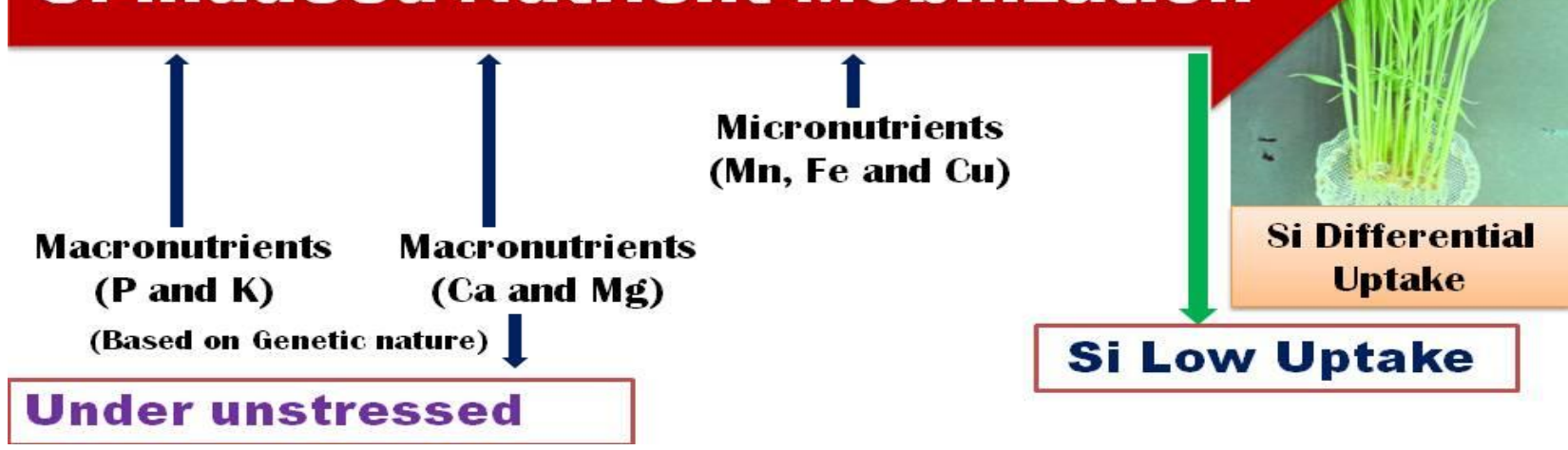

Figure 8. A schematic diagram: depicting the impact of silicon on nutrient mobilization and its relationship

Journal of Experimental Biology and Agricultural Sciences http://www.jebas.org 


\section{Acknowledgments}

The authors wish to acknowledge to the Department of Science \& Technology, Govt. of India for providing the instrumental facilities under the FIST grant. This research was financial supported by DST-Inspire. We also thank the SAIF, IIT Bombay for providing SEM-EDX analysis.

\section{Conflict of Interest}

The authors declare that there is no conflict of interest regarding the publication of this research paper.

\section{References}

Agostinho F, Tubana B, Martins M, Datnoff L (2017) Effect of Different Silicon Sources on Yield and Silicon Uptake of Rice Grown under Varying Phosphorus Rates. Plants 6: 35. DOI: doi: 10.3390/plants6030035.

Carrasco-Gil S, Rodríguez-Menéndez S, Fernández B, Pereiro R, de la Fuente V, Hernandez-Apaolaza L (2018) Silicon induced Fe deficiency affects $\mathrm{Fe}, \mathrm{Mn}, \mathrm{Cu}$ and $\mathrm{Zn}$ distribution in rice (Oryza sativa L.) growth in calcareous conditions. Plant Physiology and Biochemistry 125: 153-163.

Chen HM, Zheng CR, Tu C, Shen ZG (2000) Chemical methods and phytoremediation of soil contaminated with heavy metals. Chemosphere 41:229-234.

Chen W, Yao X, Cai K, Chen J (2011) Silicon alleviates drought stress of rice plants by improving plant water status, photosynthesis and mineral nutrient absorption. Biological Trace Element Research 142: 67-76.

Chen D, Chen D, Cao B, Wang S, Liu P, Deng X, Yin L, Zhang S (2016) Silicon Moderated the K Deficiency by Improving the Plant-Water Status in Sorghum. Scientific Reports 6:1-14.

Cuong TX, Ullah H, Datta A, Hanh TC (2017) Effects of SiliconBased Fertilizer on Growth, Yield and Nutrient Uptake of Rice in Tropical Zone of Vietnam. Rice Science 24: 283-290.

DACFW (2017) Annual report 2016-17, Department of Agriculture Cooperation and Farmers Welfare, Government of India.

DACFW (2018) Report of Committee for Doubling Farmers' Income, Department of Agriculture, Cooperation and Farmers' Welfare, Government of India.

Deren CW, Datnoff LE, Snyder GN (1992) Variable silicon content of rice cultivars grown on Everglades Histosols. Journal of Plant Nutrition 15:2363-2368.
Ensikat HJ, Ditsche-Kuru P, Barthlott W (2010) Microscopy: Science, Technology, Applications and Education. In: MéndezVilas A, Alvarez JD (Eds.), Formatex Research Center, Bajados, Spain 1: 248-255.

Epstein E, Bloom AJ (2005) Mineral nutrition of plants: principles and perspectives, 2nd edn. Sinauer Associates, Sunderland.

Etesami H, Byoung R (2018) Ecotoxicology and Environmental Safety Silicon ( $\mathrm{Si}$ ): Review and Future Prospects on the Action Mechanisms in Alleviating Biotic and Abiotic Stresses in Plants. Ecotoxicology and Environmental Safety 147:881-896.

FAOSTAT (2016) Crop database of Food and Agricultural Organization of the United Nations. Statistics Division available on www.fao.org/faostat access on 25th February, 2018.

Hammond KE, Evans DE, Hodson MJ (1995) Aluminium/silicon interactions in barley (Hordeum vulgare L.) seedlings. Plant Soil 173:89-95

Hattori T, Sonobe K, Araki H, Inanaga S, An P, Morita S (2008) Silicon application by sorghum through the alleviation of stressinduced increase in hydraulic resistance. Journal of Plant Nutrition 31: 1482-1495.

Hernandez-Apaolaza L (2014) Can silicon partially alleviate micronutrient deficiency in plants? A review. Planta 240:447-458.

Horiguchi T, Morita S (1987) Mechanism of manganese toxicity and tolerance of plants. VI. Effect of silicon on alleviation of manganese toxicity of barley. Journal of Plant Nutrition 10: 2299-2310.

Horst WJ, Marschner H (1978) Effect of silicon on manganese tolerance of bean plants (Phaseolus vulgaris L.). Plant \& Soil 50:287-303.

Horuz A, Korkmaz A (2014) The Effect of Silicon Fertilization on Reducing Salt Stress in Rice (Oryza sativa L.,). Journal of Agricultural Sciences 20: 215-229.

Iwasaki K, Maier P, Fecht M, Horst WJ (2002) Leaf apoplastic silicon enhances manganese tolerance of cowpea (Vigna unguiculata). Journal of Plant Physiology 159:167-173.

Korkmaz A, Arife K, Güney A, Hasan K (2018) The Effects of Silicon on Nutrient Levels and Yields of Tomatoes under Saline Stress in Artificial Medium Culture. Journal of Plant Nutrition 41:123-35.

Liang YC, Wong JWC, Wei L (2005) Silicon-mediated enhancement of cadmium tolerance in maize (Zea mays L.) grown in cadmium contaminated soil. Chemosphere 58: 475-483. 
Liang YC, Yang CG, Shi HH (2001) Effects of silicon on growth and mineral composition of barley grown under toxic levels of aluminum. Journal of Plant Nutrition 24:229-243.

Lobell DB, Schlenker W, Costa-Roberts J (2011) Climate trends and global crop production since 1980. Science 333:616-620.

Ma JF, Takahashi E (1990) Effect of Silicon on the Growth and Phosphprus Uptake of Rice. Plant and Soil 126: 115-119.

Ma JF, Miyake Y, Takahashi E (2001) Silicon as a beneficial element for crop plants. In: Datnoff, LE, Snyder GH, Kornd Äorfer GH (Eds.) Silicon in Agriculture, Elsevier Publication, New York, Pp.17-39.

Ma JF, Takahashi E (2002) Soil, Fertilizer, and Plant Silicon Research in Japan. Elsevier Publication.

Ma JF, Yamaji N (2006) Silicon uptake and accumulation in higher plants. Trends in Plant Science 11:392-397.

Ma JF, Yamaji N, Tamai K, Mitani, N (2007) Genotypic Difference in Silicon Uptake and Expression of Silicon Transporter Genes in Rice. Plant Physiology 145: 919-924.

Marxen A, Klotzbücher T, Jahn R, Kaiser K, Nguyen VS., Schmidt A, Vetterlein D (2016) Interaction between silicon cycling and straw decomposition in a silicon deficient rice production system. Plant and Soil 398: 153-163.

Massey F, Sue P, Hartley E (2006) Experimental demonstration of the antiherbivore effects of silica in grasses: Impacts on Foliage digestibility and Vole Growth Rates. Proceedings of the Royal Society B: Biological Sciences 273:2299-2304.

Mehrabanjoubani P, Abdolzadeh A, Sadeghipour HR, Aghdasi M (2014) Impacts of silicon nutrition on growth and nutrient status of rice plants grown under varying zinc regimes. Theoretical and Experimental Plant Physiology 27:19-29.

Nhan PP, Dong NT, Nhan HT, Chi NTM (2012) Effects of OryMaxSL and Siliysol MS on Growth and Yield of MTL560 Rice. World Applied Sciences Journal 19:704-709.
Prasad V, Stromberg CAE, Alimohammadian H, Sahni A (2005) Dinosaur coprolites and the early evolution of grasses and grazers. Science 310: 1177-1180.

Rana A, Masood A (2002) Heavy metal toxicity: effect on plant growth and metal uptake by wheat, and on free living Azotobacter. Water Air Soil Pollution 138:165-180.

Shi QH, Bao ZY, Zhu ZJ, He Y, Qian QQ, Yu JQ (2005) Silicon mediated alleviation of Mn toxicity in Cucumis sativus in relation to activities of superoxide dismutase and ascorbate peroxidase. Phytochemistry 66:1551-1559.

Sonobe K, Hattori T, An P, Tsuji W, Eneji AE, Kobayashi S, Kawamura Y, Tanaka K, InanagaS (2010) Effect of silicon application on sorghum root responses to water stress. Journal of Plant Nutrition 34: 71-82.

Swain R, Das AB, Panda, SK (2016) Genotypic response of silicon uptake ability in upland varieties of indica rice (Oryza sativa L.) and in silico analysis of silicon transporter gene (Lsi2) in var. Ghanteswari. Intentional Journal of Advanced Research 4:985-998.

Tamai K, Ma JF (2003) Characterization of silicon uptake by rice roots. New Phytologist 158:431-436.

Tamai K, Ma JF (2008) Reexamination of silicon effects on rice growth and production under field conditions using a low silicon mutant. Plant and Soil 307:21-27.

Wei-min D, Ke-qin Z, Bin-wu D, Cheng-xiao S, Kang-le, Z., Run C, Jie-yun Z (2005) Rapid Determination of Silicon Content in Rice. Rice Science 12:145-147.

Williams DE, Vlamis J (1957) The effect of silicon on yield and manganese-54 uptake and distribution in the leaves of barley plants grown in culture solutions. Plant Physiology 32: 404-409.

Yoshida S, Forno DA, Cock JH, Gomez KA (1976) Laboratory Manual for Physiological studies of Rice, 3rd edition. The International Rice Research Institute, Manila. 